\title{
PSYCHOLOGISTS AND PSYCHODRAMATISTS IN EDUCATION: AN ONLINE PROJECT DEVELOPED DURING THE PANDEMIC
}

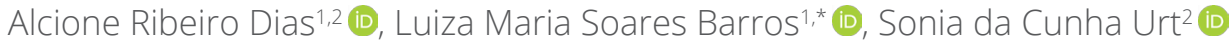

\begin{abstract}
This article presents the socionomic project Ouvindo a Escola (Listening the School) and its developments, a set of socio-psychodramatic practices carried out during the year 2020, generated in remote mode and in times of pandemic. We start by making a brief history of Educational Psychology and continue pointing Psychodramatic Pedagogy as a transformative perspective in the socio-educational field. The project involved 11 psychodramatists, 39 teachers and 15 public school workers. We intend to give visibility to referenced practices that can contribute to Critical School Psychology within the scope of public education and propose ways of action, in times of social isolation.
\end{abstract}

KEYWORDS: Psychology; Education; Psychodrama; Pandemic.

\section{PSICÓLOGOS E PSICODRAMATISTAS NA EDUCAÇÃO: PROJETO EM FORMATO ON-LINE DESENVOLVIDO NA PANDEMIA}

\section{RESUMO}

Este artigo apresenta o projeto socionômico Ouvindo a Escola e seus desdobramentos, um conjunto de práticas sociopsicodramáticas realizadas durante o ano de 2020, gerado em modo remoto e em tempos de pandemia. Iniciamos fazendo um breve histórico da Psicologia Educacional e seguimos apontando a Pedagogia Psicodramática como perspectiva transformadora no campo socioeducativo. O projeto envolveu 11 psicodramatistas, 39 professores e 15 funcionários, trabalhadores de escolas da rede pública de ensino. Pretendemos dar visibilidade a práticas referenciadas que possam contribuir para a Psicologia Escolar Crítica no âmbito da educação pública, em tempos de isolamento social.

PALAVRAS-CHAVE: Psicologia; Educação; Psicodrama; Pandemia.

\section{PSICÓLOGOS Y PSICODRAMATISTAS EN EDUCACIÓN: PROYECTO EN LÍNEA DESARROLLADO EN LA PANDEMIA}

\section{RESUMEN}

En este artículo se presenta el proyecto socioeconómico Ouvindo a Escola (Escuchando la Escuela) y sus desarrollos, un conjunto de prácticas socio-psicodramáticas realizadas durante el año 2020, generadas en modo remoto y en tiempos de pandemia. Comenzamos con una breve historia de la Psicología de la Educación y seguimos apuntando a la Pedagogía Psicodramática como una perspectiva transformadora en el ámbito socioeducativo. El proyecto involucró a 11 psicodramatistas, 39 maestros y 15 empleados, trabajadores de escuelas públicas. Pretendemos dar visibilidad a prácticas referenciadas que puedan contribuir a la Psicología Escolar Crítica en el ámbito de la educación pública y proponer formas de actuación, en tiempos de aislamiento social.

PALABRAS-CLAVE: Psicología; Educación; Psicodrama; Pandemia.

\footnotetext{
1.Associação Entre Nós - Campo Grande (MS), Brazil.

2.Universidade Federal de Mato Grosso do Sul - Campo Grande (MS), Brazil.

*Correspondence author: luizapsicodrama@gmail.com

Section editor: Graziela Gatto

Received: 21 Jan 2021 | Accepted: 17 Mar 2021
} 


\section{THE PSYCHOLOGIST AND THE EDUCATIONAL FIELD}

The history of the work of psychologists in the field of Education in Brazil is expressed in the same trajectory of Psychology as a science and profession. Research work in the scientific field ${ }^{1}$ shows that the relationship between Psychology and Education dates back to the colonial period, but the profession of psychologist in Brazil was regulated only in 1962. Until the 1970s, what could be called a "School" Psychology existed. "The pioneers of Educational and School Psychology, as a professional practice, focused mainly on those who did not learn, did not read and write and did not accept school rules" (Souza et al., 2014, p. 123). The mark of this period was the generation of a model of action aimed at diagnosis, psychometry, individuality, dealing with the treatment of so-called "learning disorders" of problem children through clinical or behavioral analyzes.

Also, according to Souza et al. (2014), from the 1980s, Maria Helena Souza Patto (1984) produced important contributions to the field of Education, among them the definition of the concept of school failure (Patto, 1987). In a broader perspective as to its origin, in which the macro-structural issues of the capitalist system are implicated, articulated with educational policies and the school routine, school failure starts to be considered a product of the school and "for this reason, it cannot be treated as an individual phenomenon and decontextualized from institutional, pedagogical, social and cultural relations" (Souza et al., 2014, p. 124).

This new proposal for the psychologist's work initially focused on the models presented by the institutionalist movement, which was strengthened in the 1970s and 1990s and which, in Latin America, had representatives from French Psychoanalysis and Socioanalysis (Rodrigues et al., 2001). Later, Critical School Psychology came to take over the theories of Piaget, Vigotski and Wallon (Barbosa, 2011). More than 30 years after the first criticisms of the psychologist's role in Education, the professionals' permanent struggle for constructing the role, theoretical deepening and methodological advances in this field continue (Souza et al., 2014).

O Conselho Federal de Psicologia-CFP (Federal Council of Psychology), in 2013, it made available to society the first edition of the Technical References for the psychologist 's performance in basic education (Referências técnicas para a atuação do psicólogo na educação básica). The second edition, revised and published in 2019, was the result of an articulated technical and political effort by class entities - councils and associations -, having contributed to the approval of Law No. 13,935, which provides for the inclusion of the psychologist in public networks of Basic Education, sanctioned at the end of 2019.

The document "seeks to address basic education as a fundamental human right, in a critical perspective, based on human diversity and a protagonist in the fight against prejudice, racism, poverty and income distribution" (Conselho Federal de Psicologia, 2019, p. 8). Placing Psychology in its place of science and profession, the document goes beyond Basic Education, addressing the ethical and political commitment of the psychologist and emphasizing the responsibility of the role as a social actor in an emancipatory project for society. The document affirms the important contribution of the psychologist on the path to overcoming individualizing and medicalizing practices and considering the complexity of social relationships that affect human development and learning processes (Tunes et al., 2006).

Education was confirmed, in Brazil, as a right of all by the Federal Constitution of 1988. However, we live with a reality that is far from presenting conditions for the actual fulfillment of constitutional law or access to equal rights to all social strata. We live with a social inequality that constitutes, as stated by Dias and Urt (2020, p. 32), "the biggest ecological problem of our time". This naturalized reality is configured in a framework that generates disparities and precariousness in the conditions of Education, in the teaching-learning process, in social life, in history and culture.

The dominant ideology in our neoliberal, capitalist-productivist society, reinforces the construction of subjectivities that contribute to tadopting individualizing and fragmented practices. This way of operating can distort the social role of the psychologist, impelling professionals towards visions and procedures that encourage pathologization. This reproduction model adopted by the professional, often unconsciously, can cause the emptying of their role.

At school, the psychologist finds a vast space for socialization that favors experiences and knowledge production for life, integrating children and young people into important social networks for their education (CFP, 2019). Contextualizing

$\overline{1 . M a s s i m i}(1984,1990)$, Massimi \& Guedes (2004), Antunes (1991, 2001) and Barbosa (2011). 
the role given the ultimate purpose of the school, which is the socialization of knowledge (Saviani, 2019), the psychologist can, in the performance of their role, contribute to the construction of an ethical, scientific and autonomy-generating path.

\section{A TRANSFORMING PERSPECTIVE: PSYCHODRAMATIC PEDAGOGY}

The psychologist's role in Education is part of a society in deep crisis imposed by capitalism and disguised by neoliberal strategies that remove the sense of humanity. In this context, we assume that these professionals probably need theoretical bases and methods that strengthen the performance of their social role. Facci \& Lessa (2011) defend the use of a historical method to understand this crisis and the contradictions of capitalist society. The authors affirm that if the school 'goes bad', it is because society cannot deal with all the present problems and that the school, every day, is losing more its teaching function (Facci \& Lessa, 2011).

There are great demands on the psychologist in their welcoming, mediating conflicts and supporting the tensions of confronting the contradictions present in people, groups and society. These tensions are amplified, by living with a reality of extreme poverty and social inequality, by the subjection that the class system imposes and by facing issues of race and gender that deeply mark a field of relations governed by intolerance, negativism and separatism. Besides, it is necessary to consider that "the triumph of neoliberalism and its crisis changed the terms of economic and political life and brought about an anthropological, social transformation, producing new figures of subjectivity” (Negri \& Hardt, 2014, p. 21).

According to these authors, these figures are: the indebted, the mediatized, the securitized and the represented. The hegemony of finance produced the indebtedness; the control of information on the network creates the mediatized; the social security and instability regime brings the figure oppressed by fear, the securitized; the corruption of democracy created the depoliticized figure of the represented (Negri \& Hardt, 2014). In the scope of Education, Zordan and Silva (2018) include the figure, transversal to all these, of the sprinter, who, fed by the rhythm and the race for production in the current world, dominates our senses and meanings, generating subjection and emptying.

Therefore, it is noteworthy that both the appropriation of theoretical foundations and the choice of practices by psychologists in their daily work is subordinated to the conditions given socially, which affect production relations and subjectivities. Psychologists generally bring from their backgrounds - and bring into their practices - a dualistic view (individual and society) in a naturalizing perspective. Duarte (2011, p. 314) asserts that "the failure to overcome this dualistic and naturalizing view of the relations between individual and society has as one of its consequences the failure to value the social transmission of knowledge".

In this path of the construction of Educational and School Psychology, which is intended to be more critical, we add the contributions of Moreno's Socionomy ${ }^{2}$ (1889-1974), more specifically from the Psychodramatic Pedagogy of Romaña ${ }^{3}$ (1927-2012), in the direction of strengthening the psychologist's social role in Education and the consolidation of a grounded and socially committed practice. The psychologist who specializes ${ }^{4}$ in Socionomy, in the field of Psychodramatic Pedagogy, has the possibility to understand the nature of the socio-educational field and to be based on a relational, historical and critical conception of Education and the human being. Psychodramatic Pedagogy is an important mediating element in the transposition of the Morenian method to the educational field.

Romaña, starting from her praxis as an educator - in the 1950s and 1960s -, created an initially called the psychodramatic educational method. Later, due to expanding the conceptual and technical scope, redefined as Psychodramatic Pedagogy (Romaña, 1985, 2012).

Psychodramatic Pedagogy is a didactic-methodological proposal that recognizes the educational value present in Socionomy (Moreno, 1975, 2020). Romaña describes, in her publications, the application of the instruments, contexts and

2.Jacob Levy Moreno, between the 1920s and 1940s, he built Socionomia - science of group laws -, known worldwide as Psychodrama, establishing its foundations and methods, being the scientific proponent of group psychotherapy. Psychiatrist and social scientist, his group studies as linked networks laid the foundation for social media (Moreno, 2016). In this article we will refer to his science - Socionomy - also using the term Psychodrama.

3.Maria Alicia Romaña (1927-2012) - Argentine, educator and pedagogue - worked with Psicodrama and lived in São Paulo from 1976 to 2005 . She was part of the first group of trainees in Psychodrama by the Argentine Association of Psychodrama (Associação Argentina de Psicodrama) in the 1960s. He presented the idea of Educational Psychodrama to Moreno, at the IV International Psychodrama Congress, in 1969, in Buenos Aires, and trained numerous psychodramatists in the socio-educational, non-psychotherapeutic focus in Brazil (Romaña, 2019).

4.The specialization in Socionomy and Psychodramatic Pedagogy takes place in schools associated with the Brazilian Federation of Psychodrama (Federação Brasileira de Psicodrama-Febrap). 
stages present in the method of dramatic action and the philosophical and theoretical principles of Socionomy that enabled the proposition of Psychodramatic Pedagogy. It refers to the Morenian concepts of spontaneity, creativity and cultural preservation. It discusses the Morenian vision of the human being - how to be in a relationship and the reparative capacity of the groups - and the group as "an organism that is potentializing, regulating and self-managing [...]" (Romaña, 2019, p. 31). Romaña highlights Sociometry and the identity matrix theory, highlighting its marks in human actions, in assuming social roles (Romaña, 2019).

Vigotski's thought was also added to Psychodramatic Pedagogy, especially concerning the psychological formation of the human being, which, in this perspective, takes place from the outside in; for the author, man is modeled by the relationship with the external world and with other men (Vigotski, 2000). Romaña values themes supported by Vigotski, such as: the creative impulse of a human being for the production of instruments (objects, machines and people - as a mediating instrument) that expand their possibilities, and the symbolic systems, each day more complex, created by man from of signs and instruments. As language is the symbolic system par excellence, it is in the relationship between language and thought that the human being produces a qualitative leap in psychological development and gradually develops his superior psychological functions: the ability to plan, predict, imagine, compare, abstract, make sense and create (Romaña, 2019).

Psychodramatic Pedagogy adds to the psychologist's practice - psychodramatist - the understanding that the perception and analysis of psychological phenomena, both from Socionomy and from Historical-Cultural Psychology, must take into account the dynamic individual/society unit. Moreno (2008) assumes that understanding the individual/collective intersection or of the human-in-relationship is in the unveiling of the social trichotomy, the three inseparable dimensions, namely: the external society, the social reality and the sociometric matrix. Vigotski (1996) deals with the necessary apprehension of psychological phenomena in their procedurality and historicity, which calls into question precisely the dynamic individual/ society unit postulated by the dialectic.

Martins and Pasqualini (2015), when explaining the functional affective process: emotion and feeling, proposed by Vigotski, clarify that human activity is an affective-cognitive unit and those affective and cognitive aspects are indissoluble in consciousness

To understand the individual in its concreteness as a basis for the professional performance of the psychologist, it is necessary to look beyond the immediate singularity, capturing the particular and universal determinations that condition the individual's particular condition, analyzing how the singularity is constructed with genericity. This is a condition for a critical professional performance that has the humanization of man as a horizon. (Martins \& Pasqualine, 2015, pp. 370-371).

Romaña (2012) considers the binomial affection and cognition as a condition for human learning and adds that Psychodramatic Pedagogy is "an appropriate pedagogical instrument to face the characteristics of today's society", being an alternative to repetition, reproduction and homogeneous ( .57$)$. Romaña's theoretical-practical insights into dramatic realization highlight the experience of the real, symbolic and imaginary (fantasy) plans as precious resources of the socionomic proposal. Psychodramatic Pedagogy uses Socionomy techniques and methods to improve the understanding of topics or content, already known or not, and to facilitate social integration (of the group) and open new perspectives for acting and relating. This way of working with Education favors the collective construction of knowledge and expands the ability to socialize knowledge in the teaching-learning process (Romaña, 1985, 2019).

The psychologist, educator or psychodramatist who opts for Psychodramatic Pedagogy does not just change working technology. In addition to a research technology or an active pedagogical method for the socio-educational field, the aim is, with Psychodramatic Pedagogy, to consolidate procedures that dialogue with the foundations of an updated and critical psychology and expand the possibilities in educational praxis. The proposal of Psychodramatic Pedagogy does not agree with the path of the liberal-pragmatist view, whose role tends to adjust individuals to the changing social reality (Romaña,2012).

As Saviani (2019) points out, school productivity and counter-hegemonic essays coexisted between the years 1980 and 1991 (with critical and counter-hegemonic pedagogies seeking to guide educational practice). The new post-crisis conditions 
of capitalism, in the 1970s, related to the transition from Fordist and Taylorist methods to toytists, created a demand in the labor market that reached school education, maintaining the belief in the contribution of Education in the economicproductive. This moment is marked by the so-called "human capital theory" - when the human supposedly qualifies capital -, an idea already ingrained in the minds by a market society, appropriates and valued in all ways.

This period was followed - between 1991 and 2001 - by movements of neoprodutivism and its variants. The ideals of adaptability, employability, excesses and abuses of the motto "learn to learn" - consolidated in the guidelines of the 21st-century world education (Unesco) and the National Curriculum Parameters (Parâmetros Curriculares Nacionais-PCNs) - made up the new relationships between knowledge and work. In schools and organizational environments, practices took place without conceptual and theoretical precision (Saviani, 2019).

It was during this period that Romaña sought to give more consistency to the theoretical body of her proposal, adding with greater vigor to the main points of JL Moreno's Socionomy, some aspects of Paulo Freire's universe - such as praxis, ethics in the role of the educator and critical conscience - and Vigotski's revolutionary ideas - the symbolic system, mediation, synthesis, thought and speech and, above all, the understanding of the human being as a historical subject (Romaña,2019).

Based on this context, in order to face, in the field of Educational and School Psychology and its practices, an excessive valuation of instruments and techniques - to the detriment of methods and methodologies with epistemological, philosophical, ethical and theoretical bases that support them -, we propose the work with Psychodramatic Pedagogy, believing that this approach can contribute for psychologists and psychodramatists to act in order to maintain the school as a possible space for an emancipatory social insertion, combating merchandise education and contributing to building education for all.

\section{THE SOCIONOMIC PROJECT IN ONLINE FORMAT}

\section{Contextualizing}

On March 11,2020, a historic and tragic event for humanity was recorded: Tedros Adhanom, director-general of the World Health Organization (WHO), officially declared the Covid-19 pandemic, a disease caused by the new coronavirus (SARS-CoV-2). Since then, and for a year now, we have been experiencing the severe social impacts of this situation worldwide. ${ }^{5}$ Contemporary history has revealed itself in a complex system of controls, precarious work, workers' suffering and a picture of illness in society itself. The social, political, economic, scientific and cultural facts of the 20th century are determinants of this new human condition (Romaña, 2012).

The necessary social isolation imposed by the pandemic made the educational institutions, teachers and Education professionals look for alternatives to continue the educational activities in an unprecedented scenario and that has demanded quick decisions on unprecedented and highly complex issues. Under the effect of the first days of the pandemic, schools were experiencing the reality of class suspension and school interaction, in a devastating situation for the public school system, exposing the unsustainable differences in social classes and material conditions in which we live. Thus, the crisis that has already taken root became evident and questions were raised about the social role of the school in the family and society. The society of the spectacle (Debord, 1997) had it is backstage ravaged, exposing, even more, the shocking social inequality with which we live in a naturalized way and as if we could do nothing to transform it.

We will report how, in this context of the Covid-19 pandemic, a socio-economic project Ouvindo a Escola (Listening the School) was set up, anchored methodologically in Psychodramatic Pedagogy and inspired by the critical perspective of School and Educational Psychology. It is an articulated set of practices, carried out remotely by 11 psychodramatists, involving 39 teachers and 15 employees, working in public schools. We will report how the project was built, the implementation of its stages carried out remotely - via WhatsApp connections and the Zoom platform - and some partial results.

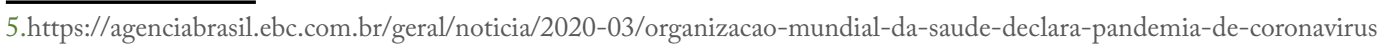


In the management and technical coordination of Associação Entre Nós ${ }^{6}$, in Campo Grande, Mato Grosso do Sul state, we had been carrying out scientifically based interventions in Socionomy and Psychodramatic Pedagogy for seven years (Kim, 2009; Romaña, 2019). The Association's purpose is the social work of strengthening bonds and building values and citizenship - usually involving the school community, especially students. Education is the main focus of Entre Nós, due to its essential role in human formation.

Since 2013, we have maintained a meaningful relationship with schools and the purpose of working directly with teachers to develop their role. The bond established with the principals of two public schools, one in a peripheral neighborhood in Campo Grande and the other in the city of Terenos, provided us with many demands. There were requests for treatment of recurrent themes in schools, such as: school dropout, socialization problems, violence, depression, ethnicity issues, early pregnancy, which we attended through the network of psychodramatists and supervised projects developed by students of the training course in Psychodrama.

At the beginning of 2020, with the reverse scenario of the pandemic and the suspension of face-to-face activities, we decided to make remote contact with school principals to make ourselves available to face the crisis.

At first, the overload of using the means of communication was already noticeable (telephone and WhatsApp), because we only got the first effective contact, in a video call, with the director of the Terenos school on a Saturday afternoon, outside of his working hours. His first expression was one of lament: "I don't think you can do psychodramas." At the end of this initial listening, the demand was directed towards meeting basic, concrete and material needs: hygiene items to prevent Covid-19, paper and printed materials that were missing due to the increased production of activities for students without Internet; and ordering basic food baskets for families that suffered from the absence of school lunches in the daily lives of children and young people. Even though it was out of our scope of work, given the circumstances, that was the help we needed to provide, remaining consistent with the purpose of our contact - being supportive and helping in whatever was necessary - and so we did.

\section{WARMING-UP}

\section{Linking with coordination}

The school where the project took place is in the municipality of Terenos and serves around 350 students, with a staff of 18 employees and more than 50 teachers. The initial objective was to listen to the school community and offer welcoming, guidance and support actions. At first, we thought that the actions could follow two aspects: support in the performance of work (professional role) and emergency psychotherapeutic care for people in psychological distress.

With basic needs gradually met, we moved forward in the dialogue and started to talk about alternatives for socioemotional support and to cope with the conditions generated by the pandemic. In contact, via WhatsApp, with the pedagogical coordinator, we followed a path similar to the one we took with the school principal: careful, patient and outof-work listening. Coordination is a role that concentrates many demands, being the connection point of the secretariat and education policies, support in the demands foreseen by the management, axis of organization of the teachers' needs in the work processes and mediator of the solutions with the students and the community.

In this period of pandemic, its duties were intensified. We started to have weekly meetings with the coordinator, to get to know the reality experienced by the school at that time. There were many difficulties for teachers in dealing with class guidelines in different WhatsApp groups, getting to know new resources such as Google classroom, forms, video classes, among others, with a high level of time pressure and lack of student access, in addition to being doing all of this in their homes, while facing their own personal and family issues. Some of the most challenging situations were already present, with sick leave even.

So the idea of a project initially came up Ouvindo o Professor (Listening to the Teacher). We prepared the text together, mapped the group of teachers under that pedagogical coordination and gave shape to that idea, creating promotional material for posting in WhatsApp groups. In fact, we formed a project management unit, the coordinator and the Association

6. The Associação Entre Nós, a non-profit organization, has carried out socio-educational activities since 2013 , was officially registered in 2016 by psychodramatists from the Núcleo de Psicodrama Gaya and had the history of its foundation and its initial works presented in a poster at the Brazilian Congress of Psychodrama, in 2016, in São Paulo (SP). 
representative, favoring that the actions were integrated into daily life, monitored and evaluated over time and generated new possibilities. Thereafter, the action was expanded to a larger scope, giving rise to the project Ouvindo a Escola, which had all actions implemented in remote format, for teachers and administrative staff, throughout 2020.

\section{Sociodramatic interviews}

The initial listening involved 30 teachers and 15 employees at Escola de Terenos and 9 teachers from other public schools. This first contact was made by the psychodramatist coordinating the project, via WhatsApp, most with a video call. The objective of the sociodramatic interview was to research the contexts, it was for them to express themselves about how they were living that moment, how they were dealing with their work, how their health and family life was, and, according to this listening, we offered the possibility continuity of support through other socio-economic activities. These initial interviews were conducted within the professional role therapy modality (Barros \& Dias, 2019), in a functional unit, director and auxiliary ego, and two group formats were formed from them: Groups Ser Professor (Being Teacher) and Administrative Team Groups.

Knowing the reality of teachers and school professionals at that time was a delicate action, as we were "entering their homes", when using the online mode. We were careful when we made the scheduling proposal, considering the difficulty of time and energy that they lived, and we showed our availability to adapt the schedule to their needs and provide the best possible conditions for the meeting. The participant opted for contact only by audio or, if allowed and had conditions, by video.

As an activity that initiated the interview, we made a brief presentation of the Association, recalling previous work developed at the school, and talked about the project's purpose, considering that they already had some information provided by the school, the principal or the pedagogical coordinator. On the specific warm-up ${ }^{7}$ at the beginning of the interview, the dialogue took place fulfilling a function of 'double', one of the basic psychodramatic techniques: in the moment of chaos in which we lived, we gave the protagonist a voice, 'speaking for it', helping them to express themselves. We made an initial speech about the great suffering caused by the pandemic and affirmed the difficulties that they should be experiencing, starting to listen to what they wanted to express, with a real interest in knowing how that person, in particular, was living life at that moment.

In a slightly more open field, the dialogue went in the direction of the effects on the professional role, in addition to investigating their health conditions: activity and rest, sleep, food and bonds. This sequence enabled a moment of greater dramatic intensity, the approach became "how" they were dealing with that moment, perceiving themselves acting - feelings, interests, needs and concerns -, intentional research on the levels of manifestation of the universe affective (Weinstein \& Fantini, 1970). The focus was kept on professional life, even though some aspects of personal and family life were brought naturally, and thus, we tried to perceive the degree of emotional suffering revealed, evaluate, guide and direct the actions that the project offered. Participation in any phase of the project's activities took place by free choice; even though it is a project assumed institutionally by the school, the freedom to participate was guaranteed.

Some teachers did not want to participate in this initial interview, stating that they did not need it and felt good. Among the 39 teachers interviewed, the majority expressed gratitude for listening, declaring that they felt supported at that moment, and more than half engaged in some project activity: socio-educational support groups and psychodramatic psychotherapy, or both, including the coordinator. Most of the teachers interviewed did not know about a psychotherapy process; of the ten they knew, eight had never considered doing so, claiming high costs. In many cases, it was challenging to find the time available to schedule an appointment, with many re-appointments occurring, probably due to the teacher's strenuous journey, especially in the pandemic. Some teachers said "I am unable to attend you" and "it is difficult to fit you on the schedule today".

These manifestations made us think about (1) the preservation of the teacher's role - after all, they are the ones who always "have to attend someone"; (2) about the teacher's ignorance, perception or belief in the possibility of benefiting

7. The specific warm-up, strictu sensu refers to the preparation of the scene, scenario and here we are making a correlation between the existing steps in the psychodramatic practice and the moments of the interview. We built the route of an interview, or even the stages of a project - as noted in the subtitles of this article, in analogy to the stages of a socionomic session. 
from psychological support; or (3) about tiredness and the fact that they are facing yet another possible online activity, requiring them time to perform.

\section{INTEGRATED ACTIONS}

At Table 1, we present the data related to the project's actions and the services carried out from April to December 2020.

Table 1. Project Ouvindo a Escola.

\begin{tabular}{|c|c|c|c|}
\hline & Integrated actions of the project & $\begin{array}{l}\text { Number of } \\
\text { participants }\end{array}$ & Additional observation \\
\hline $\begin{array}{l}\frac{0}{3} \\
\frac{\varepsilon}{\sqrt{n}} \\
\frac{1}{3}\end{array}$ & $\begin{array}{l}\text { Link with coordination } \\
\text { Early April/2020. } \\
\text { Individual interviews } \\
\text { Initial listening, reception, research and } \\
\text { referral. }\end{array}$ & 54 & $\begin{array}{l}30 \text { teachers from the School of Terenos } \\
9 \text { teachers for the Ser Professor Group from several } \\
\text { public schools } \\
15 \text { administrative staff from the same school. }\end{array}$ \\
\hline \multirow{4}{*}{ 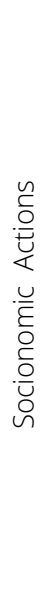 } & $\begin{array}{l}\text { School Team Groups } \\
\text { Welcome and support in the professional } \\
\text { role - } 4 \text { meetings of } 1 \mathrm{~h} 30 \mathrm{~min} \text {, in pairs/trios, } \\
\text { from August to December/2020. }\end{array}$ & 14 & $\begin{array}{l}6 \text { pairs/trios attended by functional unit: director } \\
\text { and auxiliary ego. }\end{array}$ \\
\hline & $\begin{array}{l}\text { Psychodramatic psychotherapy } \\
\text { Weekly individual assistance, for } 8 \text { months, } \\
\text { from June to December/2020. }\end{array}$ & 10 & $\begin{array}{l}4 \text { completed the process and } 6 \text { are in } \\
\text { psychotherapy. In 2020, in individual } \\
\text { psychotherapy. } \\
\text { In 2021, in group psychotherapy. }\end{array}$ \\
\hline & Ser Professor Groups - 1 and 2 welcome & 04 & $\begin{array}{l}\text { Teachers from the school where the project } \\
\text { originated. }\end{array}$ \\
\hline & $\begin{array}{l}\text { and support in the professional role }-12 \\
\text { fortnightly meetings of } 1 \mathrm{~h} 30 \mathrm{~min} \text {, in June and } \\
\text { November. }\end{array}$ & 06 & $\begin{array}{l}\text { Teachers from other public schools, who joined } \\
\text { after expanded dissemination. } \\
\text { A teacher suspended participation due to } \\
\text { technological difficulties. }\end{array}$ \\
\hline
\end{tabular}

\section{Psychodramatic psychotherapy - socioemotional support}

Even though it is not the main focus of a socio-educational project, psychotherapeutic referral was offered to those who needed to address issues of a singular or personal nature, characterized by illness or psychological distress. The ten people we referred for psychodramatic psychotherapy care faced family conflicts, sleep and anxiety disorders, pregnancy, among other issues impacted by the pandemic. From June to December, weekly consultations were carried out, with four people having completed their psychotherapeutic process and the other six continuing in group psychodramatic psychotherapy in 2021.

Clinical psychodramatists carried out the psychotherapeutic consultations from our network, who had experience with school communities, understanding the broader dimensions that affect the psychic life of the education worker. The Association paid for the professionals, remunerating them from the social table for individual appointments, which took place in remote mode. These psychotherapists worked under the guidance of the project coordinator and clinical supervision carried out in groups online, every two weeks. The supervisor and one of the psychotherapists already worked with patients online; the other professionals in psychotherapeutic care were new to this modality and were, due to the pandemic, experimenting with the use and adaptation of psychodramatic resources to this model of care.

We carried out with the psychologists the contextualized study of these services, the deeper knowledge of this vulnerable and ill reality, aggravated by the pandemic. We seek to work in a critical line, avoiding pathological and medicalizing positions, which permeate some contemporary psychotherapeutic practices. In addition to the benefit generated to the people served, in order to strengthen them in the face of a system that gets sick, we believe that we have managed to increase the awareness of the psychodramatist psychologists team about the social commitment of Psychology as a science. According to the psychotherapists' testimony, the group expanded its condition to support the confrontation of the contradictions 
arising from social issues and its view on the role of the School and Education in the formation of the human being and of a society.

\section{Ser Professor Groups - the treatment of the professional role}

For the realization of this group, we had the participation of four professionals from the Escola de Terenos, and, with the expansion of the project's dissemination, we included six teachers from other public schools in Campo Grande. We formed two Ser Professor groups to expand the condition of humanization in the performance of this social role. Each group participated in 12 biweekly virtual meetings, with a duration of $1 \mathrm{~h} 30$, on the Zoom platform, constituting a space of coexistence where we work the role of the teacher in his reality, contextualized historically and culturally.

We work in a functional unit (director and auxiliary ego) in planning during the sociodramatic session and evaluate the session after each meeting. We defined the maximum number of people in the virtual room to be six, even though the platform offers greater capacity, and we used the subgroup division into rooms to encourage contact between participants in pairs and trios. In the activities with the entire group on the screen, we used the practice of stage and audience, with the camera going out for those who were not on the scene.

Group 1, composed of three teachers and three teachers, had participants from more central schools and remained frequent throughout the meetings, with few absences, creating a solid bond between them. A teacher living in a rural area with an unstable internet signal was unable to continue, showing the unequal reality of technological resources. Group 2 was composed of four participants, three women and one man, and had a heterogeneous profile, Special Education teachers, and others who dealt with different contexts in terms of class and social condition, working in more than one teaching unit.

Based on the themes - social reality, school, students, and the teacher's role - we structured a sequence of sociodramatic meetings, seeking to diversify group actions, games, and the use of theater to bring to the scene the impacts and suffering generated by the pandemic. At each meeting, we followed the steps of the socionomic method: warm-up, dramatic action and sharing.

In the first meetings, the consequences of the current scenario in Education were discussed. From the speech of teachers, we realized the interest and the need of the group to face reality and dilemmas that, according to them, already existed in the profession. At that (and at this) moment, we were (and are) aggravated and exposed. In the initial sessions, we did activities (games; work in pairs; use of symbolic resources) that facilitated the welcome, favoring the group to get to know each other, sharing the difficulties and confrontations that they lived - in these meetings, we can say that the drama happened at the actual level.

When we entered a second stage of the groups, more specific themes emerged, leading themes in the school context: the school itself and the students, expectations and preserves. Continuing, entering a more dramatic field, we deal with the role of teacher. One of the groups raised the teacher's role and his reduced power of action, given the current challenges. There were three meetings in which they composed scenes and experimented with new responses in supposed places of power, created in the supplementary reality. In one of the shares, they made the statement that "just imagining this" place of power 'was an empowering and deeply reflecting experience" for them about their role and the context in which it takes place.

Group 1 proposed, as a way to overcome the dreaded scene, collectively build an imaginary class and give this class to the group itself, to live 'as if' back to face-to-face classes with students. The themes of the classes chosen by them were: (1) Life project and (2) The era of absurdities and science denial.

We realized that adaptations to the technological stage restrict participation, especially concerning proximity and bodily contacts, which are important for the expression, transmission and perception of emotions and information about the other. Even so, we believe that the work achieved good group dynamics and generated benefits for the participants. With Socionomy as a reference, we can say that the group meetings were intentionally therapeutic to address group issues - they dealt with the professional role (Barros \& Dias, 2019) and, at the same time, produced significant knowledge for the group. 
The teachers reported that they learned a lot about their role and among the various comments, we highlight phrases such as: "the importance of working together"; "We have been very isolated as teachers"; "We really need to humanize ourselves and also get to know and recognize each other"; "Truly human listening and exchange"; "It helped a lot to share anxieties and hopes sincerely"; "Coexistence and sharing were fundamental to deal with the moment we live in"; "The collective space regains hope and overcomes frustration in the performance of the role"; "We see the profession again as one of hope and of building a better society".

\section{School Team Groups - reviewing papers}

The school's administrative team comprises 18 people who perform the concierge tasks and access to the school, secretary, cleaning and kitchen; among them, 15 participated in individual listening interviews, and 14 joined the project. We believe that this high adherence is related to the fact that some of them had already started a face-to-face work, which unfolded in the online mode in the pandemic. All contacts were made by cell phone. Many difficulties and delays were resulting from the lack of signal and limitations in terms of technological resources. The composition of groups itself was conditioned to the possibility of participating via platforms or applications. This group only had the cell phone feature, and some even this feature, due to the capacity and credit of the cell phone.

The first meetings, via WhatsApp, welcomed and researched the feasibility of the group's services remotely and resulted in the formation of pairs and trios, who were in the same room, at the recommended protocol distance, on the day of their shifts at the School, using cell phones own or borrowed by someone from the school. The functional unit (director and auxiliary ego) planned the sequence of the meetings according to the availability of each pair/trio. Four meetings of one and a half hours each took place, and these took place between August and December 2020.

The activities developed at the school by the administrative staff had changes caused by the pandemic, and the meetings made it possible to review and reflect on this reality. Topics such as: the changes and expectations of roles, the strengthening of collective performance, the assumption of changes in activities caused by the pandemic and the coping with suffering at work and in life, in general, were discussed. These meetings resulted in the opportunity to reflect on the school's daily life, the appreciation of people and the role of each person in life and work; and in the expansion of information and knowledge concerning care with biosafety, now understood as a fundamental element in the performance of the role of each one of them.

The coordinator of the School states that the administrative team today lives an atmosphere of greater solidarity, capacity for mutual support and preparation to deal with the other; who want continuity of the meetings and who perceive themselves as 'educators' in their action with the school community.

\section{RESONANCES AND REFLECTIONS ON ONLINE MODE}

The pre-existing bond of trust, already established between the Associação Entre Nós and the School, favored us to establish the project in the pandemic scenario. Without this precondition, it would have been difficult for them to be willing to accept the help of this nature and have the necessary detachment to reveal the discomforts they were going through, and even remotely. Another decisive factor was the persistent and patient approach we had to schedule the first auditions. Serving them in their real and concrete needs, first of all, in solidarity, at the pace they needed, consolidated the path for us to make the project happen together.

It is a fact that Entre Nós' activities with schools only continued and were possible in these conditions of the pandemic, with the use of technological resources that made communication possible, even from a distance. The development of actions remotely favored the participation of teachers and employees, avoiding commuting, shortening distances and maintaining social isolation. The via - WhatsApp - demanded attention regarding the warming-up of the protagonists and patience to deal with difficulties, markdowns and interruptions due to low internet speed and oscillating signal, which made contact difficult. On the Zoom platform, the group warmed up for the action method was longer, required more session time than if the proposal was developed in a person. The remote mode of communication, and the virtual presence, cause a predisposition to the excessive use of speech from the rational field and demands from the functional unit more attention in the details of the participants' participation and emotional expression. 
The online meetings - considering the possible reality - seemed to us sufficiently generators of a productive human interaction. Links were established there and confirmed based on what was experienced and declared in the meetings. The project consolidated itself as another possibility for sociodramatic work in the educational field, having been evaluated by the participants as a space that generated personal and professional benefits, learning about the group and stimulating coexistence between peers, in addition to providing relief from tensions and pleasure with its playful method.

Psychodramatic Pedagogy, as structuring of online group meetings and moving stimulating and creative technical resources, contributed to triggering the dialogue with the foundations of an updated and critical psychology that integrates philosophy, method, and technique in educational praxis. We know that the liberal-pragmatist tendency is to adjust individuals to social reality, which is constantly changing (Romaña, 2012); therefore, we need to be aware of the prospect of online psychodrama as "the practice of the new times". We need to know more about this new reality loaded with symbolic complexities. Indeed, this has been an alternative for survival in times of social isolation. However, the human being needs material reality, the other concrete, to become human. Let us consider it premature to conclude that the remote presence produces the same quality as the effects of a group with physical presence and eye to eye.

In carrying out socio-dramatic actions, the psychodramatists of the Ouvindo a Escola project, together with educators, faced the contradictions that the historical moment of the pandemic precipitated on the stage of life and broadened their view of the socio-educational reality. Let us remain attentive to the science we practice - Socionomy - remembering that there are no politically neutral choices. From the experience of distance contact generated by the pandemic, we perceive more the pre-existing "social isolation" related to class differences. Therefore, online technological actions need to consider the reality of the digital divide. In a society as materially unequal as ours, we either keep this at the center of our transforming attention and intention, or we will be alienated from social reality.

As Dias \& Urt (2020) say, we need to continue in an attempt to "expand knowledge and seek ways of collective coping" (p. 15). This was another small step in the encounter of Psychodrama and Education and the historical trajectory of Psychology.

\section{AUTHORS' CONTRIBUTION}

Conceptualization: Dias AR, Urt SC; Investigation: Dias AR, Barros LMS; Writing - Original Draft: Dias AR, Barros LMS.

\section{DATA AVAILABILITY STATEMENT}

Not applicable.

\section{FUNDING}

Not applicable.

\section{ACKNOWLEDGMENT}

Not applicable.

\section{REFERENCES}

Antunes, M. A. M. (1991). O processo de autonomização da psicologia no Brasil - 1890/1930: Uma contribuição aos estudos em história da psicologia [Tese de Doutorado, Pontifícia Universidade Católica de São Paulo].

Antunes, M. A. M. (2001). A Psicologia no Brasil: Uma leitura histórica sobre sua constituição (2a ed.). Educ/Unimarco. 
Barbosa, D. R. (2011). Estudos para uma história da psicologia educacional e escolar no Brasil [Tese de Doutorado, Universidade de São Paulo].

Barros, L. M. S., \& Dias, A. R. (2019). Terapia do Papel Profissional: Uma modalidade socionômica de trabalho. Revista Brasileira de Psicodrama, 27(2), 236-241. https://doi.org/10.15329/2318-0498.20190025

Conselho Federal de Psicologia (2019). Referências técnicas para atuação de psicólogas(os) na educação básica. CFP.

Debord, G. (1997). A sociedade do espetáculo. Contraponto.

Dias, A. R., \& Urt, S. C. (2020). Socionomia e Ecologia: Considerações para o campo educacional. In E. L. B. Chleba, \&

C. T. Romano (Orgs.), Encontro com a Sustentabilidade: Contribuiçôes do Psicodrama (pp. 25-32). Polobooks.

Duarte, N. (2011). Vigotski e o "aprender a aprender": Crítica às apropriaçôes neoliberais e pós modernas da teoria vigotskiana. Autores Associados.

Facci,M. G. D., \& Lessa, P. V. (2011). A atuação do psicólogo no ensino público do Estado do Paraná. Revista Semestral da Associação Brasileira de Psicologia Escolare Educacional,15(1),131-141.https://doi.org/10.1590/S1413-85572011000100014

Kim, L. M. V. (2009). Psicodrama e intervenção social. Revista Brasileira de Psicodrama, 17(2), 25-32.

Martins, L. M., \& Pasqualini, J. C. (2015). Dialética singular-particular-universal: Implicações do método materialista dialético para a psicologia. Psicologia \& Sociedade, 27(2), 362-371. https://doi.org/10.1590/1807-03102015v27n2p362

Massimi, M. (1984). História das ideias psicológicas no Brasil em obras do periodo colonial. [Dissertação de Mestrado, Universidade de São Paulo].

Massimi, M. (1990). História da Psicologia brasileira: Da época colonial até 1934. EPU.

Massimi, M., \& Guedes, M. C. (2004). História da Psicologia no Brasil: Novos estudos. EDUC/Cortez.

Moreno, J. D. (2016) Impromptu Man:J. L. Moreno e as origens do psicodrama, da cultura do encontro e das redes sociais (Y. B. Datner, Trad.). Febrap.

Moreno, J. L. (1975) Psicodrama. Cultrix.

Moreno, J. L. (2008). Quem sobreviverá? Fundamentos da sociometria, da psicoterapia de grupo e do sociodrama (Edição do Estudante). Daimon.

Moreno, J. L. (2020). Sociometria, método experimental e a ciência da sociedade: Abordagem para uma nova orientação politica. Febrap.

Negri, A., \& Hardt, M. (2014). Declaração: Isto não é um manifesto. N 1 Edições.

Patto, M. H. S. (1984). Psicologia e Ideologia: Uma introdução crítica à Psicologia. T. A. Queiroz.

Patto, M. H. S. (1987). A produção do fracasso escolar: Histórias de submissão e rebeldia. [Tese de Livre Docência, Universidade de São Paulo].

Rodrigues, H. B. C., Fernandes, P. J., \& Duarte, M. das G. dos S. (2001). Plataforma Argentino: Trajetória de constituição de uma análise em ato da instituição psicanalítica. Perfil, 12, 43-56.

Romaña, M. A. (1985). Psicodrama pedagógico. Papirus.

Romaña, M. A. (2012). Sociedade de Controle e Pedagogia Psicodramática. Revista Brasileira de Psicodrama, 20(1), 57-70.

Romaña, M.A. R. (2019). Pedagogia Psicodramática e Educaşão Consciente: Mapa de um acionar educativo (A. R. Dias, Trad.). Associação Entre Nós.

Saviani, D. (2019). História das ideias pedagógicas do Brasil (5a ed.). Autores Associados.

Souza, M. P. R., Ramos, C. J. M., Lima, C. P., Barbosa, D. R., Calado, V.A., \& Yamamoto, K. (2014). Atuação do psicólogo na educação: Análise de publicações científicas brasileiras. Psicologia da Educação, 38, 123-138.

Tunes, E., Tacca, M. C. V. R., \& Martinez, A. M. (2006). Uma crítica às teorias clássicas da aprendizagem e à sua expressão no campo educativo. Linhas Críticas, 12(22), 109-130. 
Vigotski, L. S. (1996). O significado histórico da crise da Psicologia. In: L. S. Vigotski, Teoria e método em psicologia (pp. 203-417). Martins Fontes.

Vigotski, L. S. (2000). Manuscrito de 1929 (Psicologia concreta do homem). Educação E̋ Sociedade, 21(71), 21-44. (Obra original publicada em 1929). https://doi.org/10.1590/S0101-73302000000200002

Weinstein, G., \& Fantini, M. D. (1970). La Enseñanza por el afecto: Vida emocional y aprendizaje. Praeger Publishers/ Fundação Ford/Editorial Paidós.

Zordan, P. B. M. B. G., \& Silva, Z. M.T. (2018). Figuras da crise: Cidades e educação. Revista Brasileira de Educação, 23. 